See discussions, stats, and author profiles for this publication at:

https://www.researchgate.net/publication/260058652

\title{
Value-creating mechanisms within the market orientation-performance relationship: A meta-analysis
}

Article in Journal of Strategic Marketing · February 2014

DOI: 10.1080/0965254X.2013.876073

CITATIONS

6

2 authors:
READS

77

Some of the authors of this publication are also working on these related projects:

Project Olympic Games View project 
This article was downloaded by: [Anahit Armenakyan]

On: 22 May 2014, At: 15:13

Publisher: Routledge

Informa Ltd Registered in England and Wales Registered Number: 1072954 Registered

office: Mortimer House, 37-41 Mortimer Street, London W1T 3J H, UK

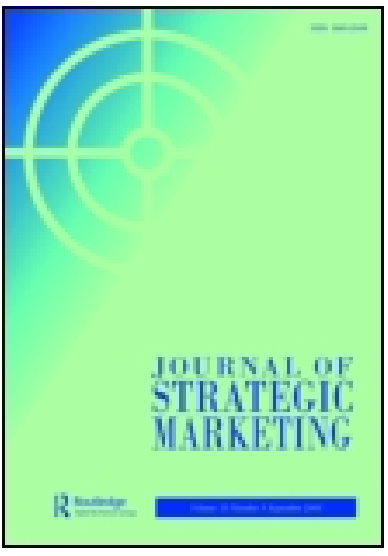

\title{
J ournal of Strategic Marketing
}

Publication details, including instructions for authors and subscription information:

http:// www.tandfonline.com/loi/ rjsm20

\section{Value-creating mechanisms within the market orientation-performance relationship: a meta-analysis}

\author{
James D. Doyle ${ }^{a} \&$ Anahit Armenakyan ${ }^{b}$ \\ a School of Business, The University of North Carolina, Pembroke, \\ NC, USA \\ ${ }^{\mathrm{b}}$ School of Business, Nipissing University, North Bay, Ontario, \\ Canada \\ Published online: 05 Feb 2014.
}

To cite this article: J ames D. Doyle \& Anahit Armenakyan (2014) Value-creating mechanisms within the market orientation-performance relationship: a meta-analysis, J ournal of Strategic Marketing, 22:3, 193-205, DOI: 10.1080/ 0965254X.2013.876073

To link to this article: http:// dx.doi.org/ 10.1080/ 0965254X.2013.876073

\section{PLEASE SCROLL DOWN FOR ARTICLE}

Taylor \& Francis makes every effort to ensure the accuracy of all the information (the "Content") contained in the publications on our platform. However, Taylor \& Francis, our agents, and our licensors make no representations or warranties whatsoever as to the accuracy, completeness, or suitability for any purpose of the Content. Any opinions and views expressed in this publication are the opinions and views of the authors, and are not the views of or endorsed by Taylor \& Francis. The accuracy of the Content should not be relied upon and should be independently verified with primary sources of information. Taylor and Francis shall not be liable for any losses, actions, claims, proceedings, demands, costs, expenses, damages, and other liabilities whatsoever or howsoever caused arising directly or indirectly in connection with, in relation to or arising out of the use of the Content.

This article may be used for research, teaching, and private study purposes. Any substantial or systematic reproduction, redistribution, reselling, loan, sub-licensing, systematic supply, or distribution in any form to anyone is expressly forbidden. Terms \& Conditions of access and use can be found at http://www.tandfonline.com/page/termsand-conditions 


\title{
Value-creating mechanisms within the market orientation-performance relationship: a meta-analysis
}

\author{
James D. Doyle ${ }^{\mathrm{a} *}$ and Anahit Armenakyan ${ }^{\mathrm{b}}$ \\ ${ }^{a}$ School of Business, The University of North Carolina, Pembroke, NC, USA; ${ }^{b}$ School of Business, \\ Nipissing University, North Bay, Ontario, Canada
}

(Received 26 July 2013; accepted 27 August 2013)

\begin{abstract}
The authors use meta-analysis to identify organizational mechanisms within the market orientation-performance relationship and to assess the implications of correlations between market orientation and complementary organizational orientations for that relationship. The meta-analysis is based on an integration of extant research of the relationships between market orientation and value-creating marketing capabilities as well as between organizational performance and market orientation, complementary organizational orientations, and value-creating marketing capabilities. The metaanalysis identifies the unique contribution of market orientation to organizational performance. Relationships between market orientation and specific organizational orientations detract from the necessity of market orientation as a precursor to organizational performance. Consistent with expectations, market orientation was found to relate differentially but still more strongly to specific types of firm-level valuecreating marketing capabilities than to organizational performance. Results indicate that market orientation may affect performance primarily through its relationships with value-creating marketing capabilities.
\end{abstract}

Keywords: market orientation; capabilities; processes; performance; meta-analysis

Concern has been expressed that more conclusive knowledge of the business processes and organizational capabilities that transform organizational resources into superior organizational performance is needed (Morgan, Vorhies, \& Mason, 2009; Zhou, Brown, \& Dev, 2009). This paper represents an attempt to address this particular need within the specific context of the relationship between market orientation (MO), an organizational resource, complementary organizational orientations, and organizational performance $(\mathrm{P})$. Organizational resources may be necessary inputs for the conception and implementation of strategies that improve firm efficiency or effectiveness (Barney, 1991), but customer, market, and financial performance occur not because a resource is possessed but because and how that resource is deployed (Day, 1994; Hult, Ketchen, \& Slater 2005; Ketchen, Hult, \& Slater 2007). Although it has long been appreciated that MO is a positive organizational performance antecedent, the assertion that MO 'is likely to have its effects demonstrated through the strategic actions of an organization' (Foley \& Fahy, 2009, p. 16) suggests needs for identifying the processes and capabilities that demonstrate or occur because of $\mathrm{MO}$ and for assessing the extents to which they are responsible for transforming MO into superior organizational performance.

Recent MO research shows increasing interest in unpacking the firm-specific organizational processes and capabilities that result in value creation (e.g., Hult et al.,

*Corresponding author. Email: james.doyle@uncp.edu 
2005; Jiménez-Jiménez \& Cegarra-Navarro, 2007; Langerak, Hultink, \& Robben, 2007; Morgan et al., 2009). With the exception of a meta-analysis by Kirca, Jayachandran, and Bearden (2005) in which it was reported that a particular configuration of organizational innovativeness, product/service quality, and customer loyalty partially mediate the MO-P relationship, however, these mediating effects have not attracted much attention in metaanalytic MO studies. Compounding this concern is meta-analytic research confirming the moderate or strong positive relationships between MO and entrepreneurial, innovation, and learning orientations (Grinstein, 2008). Orientations exert influence over decisions and actions (Miles \& Arnold, 1991; Noble, Sinha, \& Kumar, 2002) and, because MO has much in common with other orientations, it is necessary to determine whether MO is a necessary prerequisite for the organizational processes and capabilities that drive superior organizational performance. Understanding the MO-P relationship in a more exhaustive sense is a pressing need for marketing researchers and practitioners, given that MO has been shown to explain as little as $4.8 \%(7.3 \%)$ of the variance in objective (subjective) measurements of organizational performance (Ellis, 2006).

This research focuses on providing answers to three questions, as illustrated in Figure 1. First, the sufficiency of MO as an organizational performance antecedent requires examination, since mere resource possession may not in itself drive organizational performance. Second, the necessity of MO as an organizational performance antecedent warrants attention, since MO correlates significantly and positively with other organizational orientations. Third, the organizational processes and capabilities that demonstrate or enact MO require specification.

\section{Theoretical framework}

The resource-based view (RBV) of the firm regards firms as bundles of heterogeneous resources and capabilities (Deligonul \& Cavusgil, 1997) and, by extension, industries as collections of heterogeneous resource and capability bundles. Intra-industry performance variance is presumed by the RBV to derive from this heterogeneity, with high-performing firms being the rare, valuable, and imperfectly imitable bundles (Barney, 1991; Fahy, Hooley, Greenley, \& Cadogan, 2006; Hooley, Greenley, Cadogan, \& Fahy, 2005). Studies conducted in accordance with corollary theories have extended this view, arguing that interfirm performance variance derives not so much from heterogeneous resource possession as from heterogeneous resource management (e.g., Hult et al., 2005). There is,

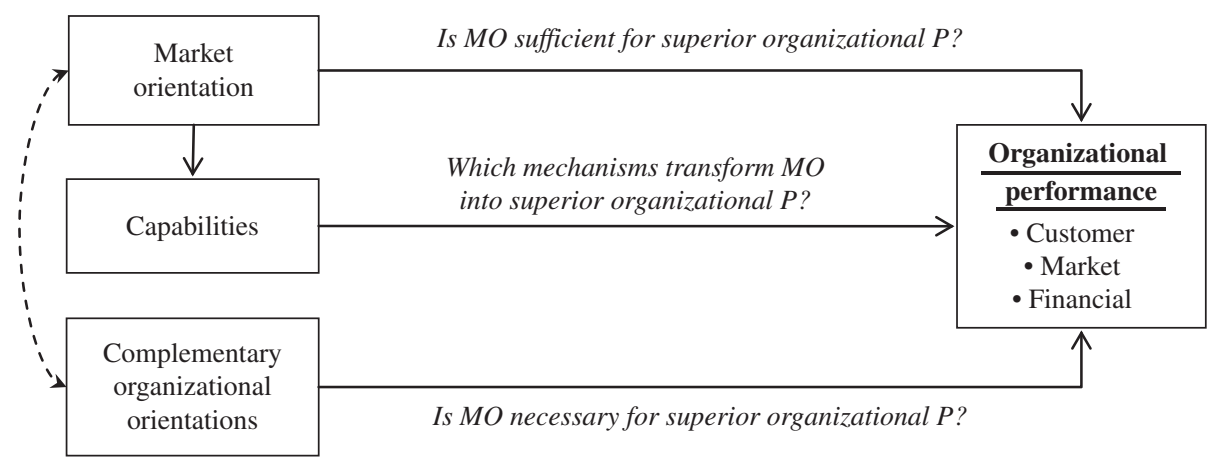

Figure 1. Research framework. 
therefore, a critical difference between resources, nouns, and the behaviors, verbs, that occur on, using, or simply because of resources (Wu, Melnyk, \& Flynn, 2010).

Deployment is considered the process through which a particular resource is implemented in support of an organization's effort to create superior customer value or achieve low relative costs. Of interest here are business processes (cf. Srivastava, Shervani, \& Fahey, 1999), particularly those that are unique in the organization or that the organization performs more effectively than peer organizations. Capabilities are the path dependent, firm-specific aptitudes, skills, and technologies for resource deployment, allocation, and coordination (Wu et al., 2010). Capabilities superior to those of competing firms are termed 'distinctive competences' (Conant, Mokwa, \& Varadarajan, 1990). A number of capability frameworks are evident in the literature. However, the suggestion by Narver and Slater (1990) that MO is a primary facilitator of customer value implies that the appropriate focus of this research is on market-related capabilities, defined as the integrative processes designed to apply the collective knowledge, skills, and resources of the firm to the market-related needs of the business' (Weerawardenaa \& O'Cass, 2004, p. 421). Market planning and marketing implementation are two sets of market-related capabilities that have been identified in prior research (e.g., Vorhies \& Morgan, 2005; Weerawardenaa \& O'Cass, 2004). Whereas market planning capabilities concern the management of market intelligence and development of marketing strategies, marketing implementation capabilities include marketing mix management, product development and commercialization management, and customer relationship management (Srivastava et al., 1999). Marketing mix capabilities encompass customer service, sales force quality, distribution network strength, and other aspects of marketing management (Weerawardenaa \& O'Cass, 2004). By contrast, product development and commercialization management as well as the management of customer relationships concern the extent to which an organization markets highly valuable products to segments of buyers and users with which it enjoys strong, ongoing relationships.

\section{Market orientation and performance}

While the nature of the MO-P relationship has only (relatively) recently been subject to empirical scrutiny, many observers note that evidence is generally supportive of the relationship that was long held as an article of faith. Still, several researchers remain critical of the MO-P relationship generally and skeptical of claims as to its universal applicability specifically (e.g., Sin, Tse, Heung, \& Yim, 2005). Moreover, unexpected results with respect to the MO-P relationship have been observed. Explanations for negative or nonsignificant main-effect $\mathrm{MO}-\mathrm{P}$ relationships are various but seem to include the effects of mediating variables (e.g., Han, Kim, \& Srivastava, 1998; Hsieh, Chiu, \& Hsu, 2008; Lonial, Tarim, Tatoglu, Zaim, \& Zaim, 2008; Zhou, Li, Zhou, \& Su, 2008), industry types and conditions (e.g., Narver \& Slater, 1990), and methodological considerations (e.g., Deshpandé, Farley, \& Webster, 1993). Of course, these studies are only a small fraction of the entire MO research corpus, and it is generally regarded that $\mathrm{MO}$ is a valuable and rare resource that relates positively with organizational performance. Hence,

Hypothesis 1: The greater the reported MO of an organization, the better its (a) customer, (b) market, and (c) financial performance.

\section{The MO-P relationship, controlling for related business orientations}

A number of studies have considered the MO-P relationship in contrast to the relationships between performance and other strategic orientations (e.g., Hult \& Ketchen, 
2001; Matsuno, Mentzer, \& Özsomer, 2002). A business orientation is the underlying philosophy of an organization within which decisions are made and in the context of which interactions within the marketplace occur (Miles \& Arnold, 1991; Noble et al., 2002). MO has been shown to relate positively to each of the entrepreneurial, innovation, and learning orientations (e.g., Grinstein, 2008). An entrepreneurial orientation is the extent to which an organization has a propensity for risk taking and is both proactive and innovative (Hong, Song, \& Yoo, 2013). Innovation orientation, and its closely linked technological orientation, is described as an inside-out process that enhances the novelty of product innovation by the organization (Kim, Im, \& Slater, 2013).

In many respects, MO implies organizational learning (OL) about markets for the purpose of creating value through deployment of outside-in resources and capabilities (Day, 1994). Indeed, 'the firm capacity for OL and the inherent capabilities exhibited are a fundamental issue in the contribution of market orientation to business competitiveness' (Morgan, 2004, p. 78). Similarly, Day (1994) suggests that 'in market-driven firms the processes for gathering, interpreting, and using market information are more systematic, thoughtful, and anticipatory than in other firms' (p. 43). As it relates to MO, OL refers to the development of potentially behavior influencing new knowledge (Slater \& Narver, 1995) regarding markets through market sensing (cf. Day, 1994) or, more practically, the acquisition, dissemination, shared interpretation, and utilization of market intelligence (Liu, Luo, \& Shi, 2003). Market sensing is a process through which firms initiate an inquiry, acquire information, distribute information, interpret information, use information, and evaluate outcomes (Day, 1994). To determine the necessity of MO against this background,

Hypothesis 2.1: Controlling for entrepreneurial orientation, the greater the reported MO of an organization, the better its performance.

Hypothesis 2.2: Controlling for innovation orientation, the greater the reported MO of an organization, the better its performance.

Hypothesis 2.3: Controlling for learning orientation, the greater the reported $\mathrm{MO}$ of an organization, the better its performance.

\section{Organizational mechanisms within the $\mathrm{MO}-\mathrm{P}$ relationship}

The preceding hypotheses were predicated on the notion that it is meaningful to assess the extent to which organizational resources relate directly with organizational performance. However, it may be of little practical significance to assert a relationship that, as Ketchen et al. (2007, p. 962) remarked, 'obviously lacks face validity.' The culture of an organization may be a vital performance factor, but it 'cannot be expected to shape performance directly,' since 'customers do not purchase a firm's goods and services simply because the firm has a particular type of culture' (Hult et al., 2005, p. 1174).

The successful market-oriented firm is the one that achieves particularly effective MO implementation by creating exceptional value for customers (Menguc \& Auh, 2006). It is therefore presumed that the nomological network that bridges $\mathrm{MO}$ and superior performance is necessarily comprised of the organizational capabilities that involve deployment of MO and have a material, positive effect on customer value.

Recent MO research appears to support the notion that MO is better considered a capability antecedent than a performance antecedent. When Morgan et al. (2009) assessed the individual main effects of MO and marketing capabilities on both objective and subjective performance measures, they found that an otherwise significant MO coefficient 


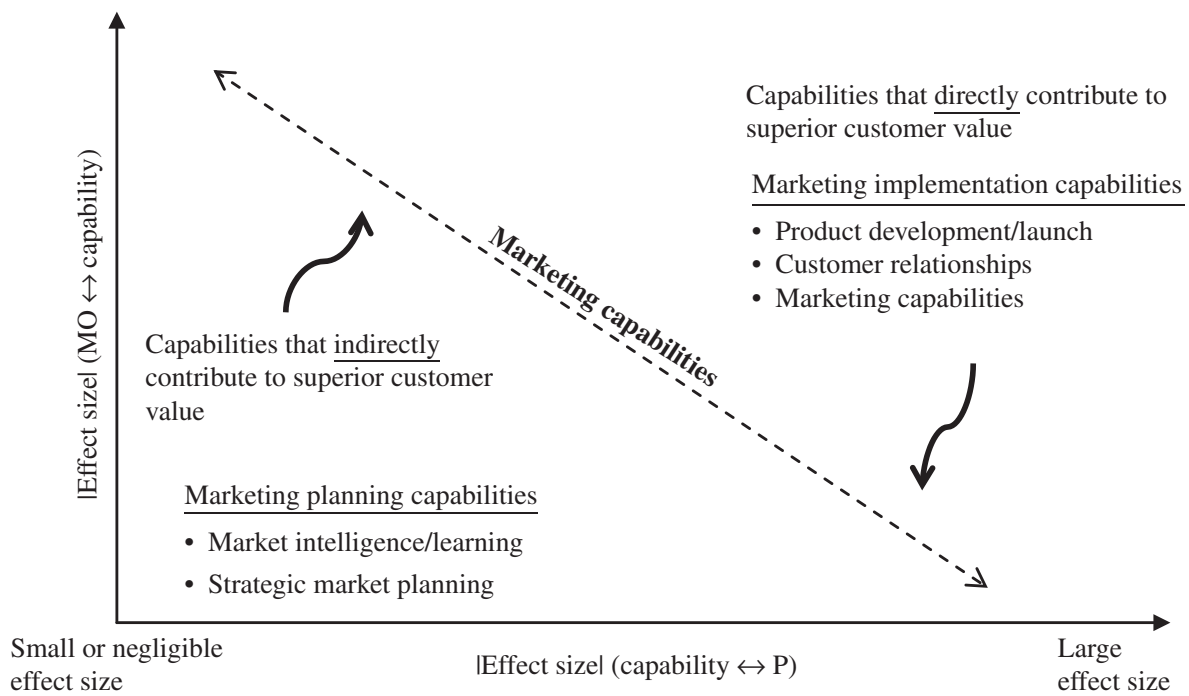

Figure 2. Hypothesized relationships between MO, organizational actions, and performance.

was rendered nonsignificant by a strong marketing capabilities coefficient. In their study of 'disparate approaches' to operationalizing MO, Hult et al. (2005) found that organizational responsiveness fully mediates the relationships between MO and performance, and between market information processing and performance. Jiménez-Jiménez and CegarraNavarro (2007) found that OL fully mediated the relationships between intelligence generation and dissemination and performance in their study of Spanish firms. Langerak et al. (2007) showed that proficient product development processes mediate the MO-P relationship in their study of Dutch firms.

Some capabilities are expected to relate to $\mathrm{MO}$ and organizational performance more directly than others, however. Figure 2 implies that MO will relate strongly to organizational capabilities that indirectly, rather than directly, contribute to superior customer value. In contrast, we expect that MO will have a relatively distal effect on marketing capabilities that are regarded for directly contributing to superior customer value.

Hypothesis 3: The effect of the reported MO of an organization on its (a) customer, (b) market, and (c) financial performance will be weaker than that of the reported MO of an organization on its market-related capabilities.

\section{Methodology}

\section{Search protocol}

Original empirical studies of the MO-P and related relationships were located and inspected in the summer of 2013. For any paper to be included in the present study, it must have been an English-language empirical work with the following keywords present in its abstract: '(market) orientation,' 'performance,' 'capability,' 'competence,' or 'process.' Necessary data for calculating effect sizes included correlation coefficients, reliability estimates, and sample sizes. A coding sheet was developed and, following a round of training, two independent coders assessed each study for its appropriateness and relevance to the present research. 


\section{Measures of market orientation}

In 1990, the Journal of Marketing published a pair of papers (Kohli \& Jaworski, 1990; Narver \& Slater, 1990) whose primary goal was to offer an operational definition and measure of MO. Today, the MO operationalizations of Kohli and Jaworski (1990; 'MARKOR') and Narver and Slater (1990; 'MKTOR') are used in most MO research (González-Benito \& González-Benito, 2005). The operational definitions of Kohli and Jaworski (1990) and Narver and Slater (1990) reflect related perspectives of MO. Specifically, Narver and Slater (1990) claim that their operational definition frames MO as a 'business culture that most effectively and efficiently creates value for customers' (p. 20) whereas Kohli and Jaworski (1990) present MO as a set of firm-level market-information processing behaviors focused on 'the organization-wide generation of market intelligence pertaining to current and future customer needs, dissemination of the intelligence across departments, and organization-wide responsiveness to it' (p. 6).

\section{Measures of organizational processes and capabilities}

Capabilities are unique, value-creating resources (Day, 1994) that, as complex skill and knowledge bundles, are exercised through business processes (Ramaswami, Srivastava, \& Bhargava, 2009). Capabilities differ from processes in that they are unique to the organization, and so they are indicated by measures specifying that informants are to indicate the extent to which their organization performs a specific process better than its major competitors (e.g., Morgan et al., 2009).

\section{Measures of three levels of organizational performance}

For our purposes, customer performance was assessed with items tapping customer satisfaction and loyalty (e.g., Hooley et al., 2005); market performance was assessed with items tapping volume, sales growth, market share, and market share growth (e.g., Ogbonna and Ogwo, 2013); financial performance was assessed with items tapping profitability (e.g., Ogbonna and Ogwo, 2013). Regardless of level, organizational performance can be assessed both in absolute and relative terms as well as in objective and subjective terms. Unlike absolute organizational performance, relative organizational performance is measured with explicit reference to a targeted organizational performance level which functions as a gauge against which realized organizational performance can be assessed. Relative organizational performance can be assessed against either the performance objectives or expectations of the informant for the sampling unit for which he or she is providing data (e.g., Kawakami, MacLachlan, \& Stringfellow, 2012) or the perceived performance of peer competitors (e.g., Menguc \& Auh, 2006). Objective organizational performance includes quantitative measures of return on assets, equity, and investment (e.g., Hult et al., 2005; Vorhies \& Morgan, 2005). Subjective organizational performance, in contrast, refers to the perceptions of informants as to the performance level of their organization.

\section{Effect size transformations}

Corrections were applied for measurement and sampling errors. Measurement error was corrected at the individual-study level by dividing the effect estimate by the product of the square root of the reliabilities of the two constructs (e.g., Ellis, 2006). Studies not reporting a measure of internal consistency were assigned a reliability value on the basis of the mean 
of other studies of that same variable. Effect sizes corrected for measurement error were then transformed to Fisher's $z_{r}$ in order to address the issue of nonnormality (Rosenthal, 1984). Mean effect sizes were calculated by weighting each effect by the inverse of its variance in order to give greater weight to larger and presumably more precise estimates. Mean effect sizes were then transformed back into standard correlational form using the inverse of the $z_{r}$ transformation.

\section{Contextual and methodological study characteristics}

Additional data collection included year of publication, country/region of data collection, market type, sector, profit orientation, informant level, and informant functional area. Informant organization size was also coded, but inconsistent approaches to measuring organization size (e.g., number of employees, as in O'Cass \& Ngo, [2011]; number of beds, as in Lonial et al., [2008]) and to defining size categories make it very difficult to compare across organizations on this dimension. From a methodological perspective, additional data collection included initial and effective sample size statistics, data collection method, and MO measure type.

\section{Analysis and results}

\section{Overview of the data-set}

Examination of studies obtained during the search process focused on substantive relevance, methodological rigor, and completeness of data. Slightly more than $41 \%$ of studies obtained during the search process were retained for the present analysis. In all, 15,801 informants $(M=259$ informants per study; $\mathrm{SD}=172.53)$ are represented in this data-set. A total of 479 effects reported in 61 studies $(M=7.85)$ that were published in 29 academic journals are represented in this analysis.

Of the 52 studies in which it was possible to make this determination, the MO-P relationship was more commonly assessed in industrial/business markets $(n=35 ; 67.3 \%)$ than consumer markets $(n=6 ; 11.5 \%)$. Eleven $(21.2 \%)$ studies involved data collection in a hybrid market. The product sector $(n=20 ; 33.3 \%)$ is featured more prominently in the MO literature than the service sector $(n=13 ; 21.7 \%)$. Twenty-seven studies $(45 \%)$, however, combined the product and service sectors into a single data-set (e.g., Morgan et al., 2009).

Several studies reported results based on an international (i.e., multicountry) sampling frame (e.g., Jaakkola, Möller, Parvinen, Evanschitzky, \& Mühlbacher, 2010). Popular countries for study include Australia $(n=7$ studies), China $(n=10)$, and the USA $(n=8)$. Although O'Cass and Ngo (2012) suggest that 'research has [generally] considered customer value and the implications of supplier firm capabilities in the US context' (p. 129) to the exclusion of other contexts, this analysis represents significant geographic and cultural variety, with studies having been conducted in Turkey (Lonial et al., 2008), India (Singh, 2009), Canada (Yannopoulos, Auh, \& Menguc, 2012), and others.

Paper-based questionnaires distributed by the postal mail system were the dominant choice (41 studies; $69.5 \%$ ) of researchers represented in the data-set. Personal interviews (12 studies; $20.3 \%$ ) and online questionnaires ( 6 studies; $10.2 \%$ ) were used by researchers with relative infrequency. Personal interviews were conducted in China ( $n=8$ studies; $66.7 \%$ of all personal interviews) as well as in India, Nigeria, Spain, and Turkey (all $n=1$ ). Preference for personal interviews appears prevalent in European countries, 
newly industrialized countries, and the developing world. Helpful for avoiding miscommunication problems and for overcoming response rate issues associated with mail surveys (Lau, 2011; Yang, Wang, \& Su, 2006), personal interviews were used in $80 \%$ of all studies conducted using Chinese data. Online questionnaire delivery was first implemented by Verhoef and Leeflang (2009), although its popularity has grown to the extent that $28.5 \%$ of studies published in or after 2011 were based on data collected via the Internet.

Executive officers, including chief executive officers, account for 197 (41.1\%) of the effects reported in this analysis (e.g., Hughes, Morgan, \& Kouropalatis, 2008). Although 65 effects $(13.6 \%)$ were drawn from studies reported data from respondents across organizational levels (e.g., marketing managers and directors; Lin, Peng, \& Kao, 2008), no study reported data provided by informants below the management level.

MKTOR was the dominant MO operationalization in the data-set. Whereas MKTOR was used 27 times in reports of bivariate relationships between MO and other strategic orientations (e.g., Li, Wei, \& Liu, 2010; Lin et al., 2008), MARKOR was used only twice (O'Cass \& Ngo, 2011). Similarly, MKTOR was implemented 23 times in examinations of bivariate relationships between MO and organizational processes and capabilities (e.g., Langerak et al., 2007) compared to six implementations of MARKOR for the same bivariate relationships (e.g., Ngo \& O'Cass, 2012). Finally, MKTOR was implemented 33 times in reports of the bivariate relationship between $\mathrm{MO}$ and organizational performance (e.g., Hooley et al., 2005) compared to four implementations of MARKOR for the same bivariate relationships (e.g., O'Cass \& Ngo, 2012). Since MARKOR is represented so infrequently in the data-set, hypothesis testing was conducted using studies in which MKTOR was the MO operationalization of choice.

\section{Tests of hypotheses}

H1 predicted a significant positive relationship between $\mathrm{MO}$ and organizational performance. In the present analysis, six studies $\left(N_{\text {Respondents }}=1915\right)$ examined the bivariate relationship between MO and customer performance. Uncorrected effect sizes ranged from $r=0.15$ (Kim et al., 2013) to $r=0.623$ (Charpavang, 2012). The corrected mean effect size for $\mathrm{MO}$ and customer performance is $r=0.49$ ( $\mathrm{SE}=0.08 ; 95 \%$ confidence interval $[\mathrm{CI}]: 0.31-0.65)$.

In the present analysis, 11 studies $\left(N_{\text {Respondents }}=3876\right)$ examined the bivariate relationship between $\mathrm{MO}$ and market performance. Uncorrected effect sizes ranged from $r=0.10$ (Jaakkola et al., 2010) to $r=0.51$ (Charpavang, 2012). The corrected mean effect size for $\mathrm{MO}$ and market performance is $r=0.40$ ( $\mathrm{SE}=0.04$; 95\% CI: 0.30-0.48). Customer orientation was assessed for its relationship with market performance an additional seven times; uncorrected effect sizes ranged from $r=0.26$ (Tay \& Tay, 2007) to $r=0.43$ (Zhou et al., 2009). Similarly, competitor orientation was assessed for its relationship with market performance an additional seven times; uncorrected effect sizes ranged from $r=-0.34$ (Tay \& Tay, 2007) to $r=0.46$ (Rhee, Park, \& Lee, 2010). Interfunctional coordination was assessed six times for its relationship with market performance, with uncorrected effect sizes ranging from $r=0.06$ (Tay \& Tay, 2007) to $r=0.43$ (Singh, 2009). In the present analysis, 16 studies $\left(N_{\text {Respondents }}=5251\right)$ examined the bivariate relationship between MO and financial performance. The corrected mean effect size for MO and financial performance is $r=0.29$ ( $\mathrm{SE}=0.03$; 95\% CI: 0.23-0.35). Using accepted guidelines (that $r \leq 0.10$ is a small effect, $r \approx 0.25$ is a medium effect, and $r \geq 0.40$ is a large effect) (Lipsey \& Wilson, 2001), MO only has a large effect on 
Table 1. Correlates of MO.

\begin{tabular}{lrrrrrr}
\hline & $\begin{array}{c}\text { Number of } \\
\text { effects }\end{array}$ & $\begin{array}{c}\text { Sample } \\
\text { size }\end{array}$ & $\begin{array}{c}\text { Corrected } \\
\text { effect size }\end{array}$ & SE & $95 \%$ CI & $\begin{array}{c}\text { Fail } \\
\text { safe }(n)\end{array}$ \\
\hline $\begin{array}{l}\text { Orientations } \\
\quad \text { Entrepreneurial }\end{array}$ & 5 & 1316 & 0.54 & 0.06 & $0.41-0.64$ & 565 \\
$\quad \begin{array}{l}\text { Innovation } \\
\quad \text { Learning }\end{array}$ & 8 & 2802 & 0.55 & 0.07 & $0.41-0.67$ & 1848 \\
$\begin{array}{l}\text { Marketing planning } \\
\quad \text { Market intelligence }\end{array}$ & 13 & 3178 & 0.66 & 0.04 & $0.55-0.74$ & 6032 \\
$\begin{array}{l}\text { Marketing implementation } \\
\quad \text { Product development }\end{array}$ & 3 & 417 & 0.65 & 0.05 & $0.51-0.75$ & 189 \\
$\quad$ Product commercialization & 5 & 1832 & 0.51 & 0.02 & $0.46-0.56$ & 678 \\
$\quad \begin{array}{l}\text { Customer relationships } \\
\quad \text { Marketing capabilities }\end{array}$ & 6 & 1558 & 0.50 & 0.03 & $0.43-0.56$ & 659 \\
$\begin{array}{l}\text { Performance } \\
\quad \text { Customer }\end{array}$ & 4 & 2006 & 0.42 & 0.05 & $0.30-0.53$ & 292 \\
$\quad$ Market & 1351 & 0.62 & 0.09 & $0.31-0.81$ & 597 \\
$\quad$ Financial & 6 & 1915 & 0.49 & 0.08 & $0.31-0.65$ & 677 \\
\hline
\end{tabular}

customer performance. In all cases, however, MO has at least a medium-level effect on organizational performance.

$\mathrm{H} 2$ predicted that certain business orientations have influence in the MO-P relationship. Table 1 shows that MO relates significantly to entrepreneurial $(r=0.54)$, innovation $(r=0.55)$, and learning $(r=0.66)$ orientations. $\mathrm{H} 2$ differs from $\mathrm{H} 1$ by explicitly controlling for the confounding effects of each of the three orientations on MO in terms of its relationship with P. It was not possible to entirely assess this issue for customer performance because of insufficient incorporation of the innovation and learning orientation constructs in extant research. Table 2 shows that relationships between MO and each of market and financial performance are affected by entrepreneurial, innovation, and learning orientations. Because of the high degree of relatedness between constructs, each MO-P relationship was significantly altered by controlling for the entrepreneurial, innovation, and learning orientations. When considered with either entrepreneurial or learning orientation, as examples, the value of $\mathrm{MO}$ as an antecedent of financial

Table 2. MO-P, controlling for each orientation.

\begin{tabular}{|c|c|c|c|c|c|c|c|c|}
\hline \multirow[b]{2}{*}{ Orientations } & \multirow[b]{2}{*}{ MO } & \multirow{2}{*}{$\begin{array}{c}\text { Effect } \\
\text { indicators }\end{array}$} & \multicolumn{2}{|c|}{ Customer } & \multicolumn{2}{|c|}{ Market } & \multicolumn{2}{|c|}{ Financial } \\
\hline & & & A & B & A & B & A & B \\
\hline \multirow[t]{3}{*}{ Entrepreneurial } & \multirow[t]{3}{*}{0.54} & $r(\mathrm{SE})$ & $0.38(0.08)$ & 0.37 & $0.41(0.04)$ & 0.23 & $0.34(0.06)$ & 0.13 \\
\hline & & $95 \% \mathrm{CI}$ & $0.19-0.54$ & & $0.34-0.48$ & & $0.21-0.47$ & \\
\hline & & Fail safe $(n)$ & 97 & & 443 & & 164 & \\
\hline \multirow[t]{3}{*}{ Innovation } & \multirow[t]{3}{*}{0.55} & $r(\mathrm{SE})$ & - & - & $0.33(0.03)$ & 0.28 & $0.21(0.08)$ & 0.21 \\
\hline & & $95 \% \mathrm{CI}$ & - & & $0.26-0.39$ & & $0.04-0.37$ & \\
\hline & & Fail safe $(n)$ & - & & 205 & & 224 & \\
\hline \multirow[t]{3}{*}{ Learning } & \multirow[t]{3}{*}{0.66} & $r(\mathrm{SE})$ & - & - & $0.38(0.04)$ & 0.21 & $0.29(0.05)$ & 0.14 \\
\hline & & $95 \% \mathrm{CI}$ & - & & $0.30-0.46$ & & $0.19-0.39$ & \\
\hline & & Fail safe $(n)$ & - & & 153 & & 378 & \\
\hline
\end{tabular}

Note: $\mathrm{A}=$ bivariate effects (performance and each orientation); $\mathrm{B}=\mathrm{MO}-\mathrm{P}$ relationship, controlling for each orientation. 
Table 3. Number and correlations (SE) between MO, marketing capabilities, and performance.

\begin{tabular}{|c|c|c|c|c|c|c|c|c|}
\hline & MO & 1 & 2 & 3 & 4 & 5 & 6 & 7 \\
\hline \multicolumn{9}{|l|}{ Marketing planning } \\
\hline 1. Market intelligence & $\begin{array}{c}n=3 \\
0.65 \\
(0.05)\end{array}$ & & & & & & & \\
\hline \multicolumn{9}{|l|}{ Marketing implementation } \\
\hline 2. Customer relationship & $\begin{array}{c}n=3 \\
0.42 \\
(0.05)\end{array}$ & - & & & & & & \\
\hline $\begin{array}{l}\text { 3. Product } \\
\text { development }\end{array}$ & $\begin{array}{c}n=5 \\
0.51 \\
(0.02)\end{array}$ & - & - & - & & & & \\
\hline $\begin{array}{l}\text { 4. Product } \\
\text { commercialization }\end{array}$ & $\begin{array}{c}n=6 \\
0.50 \\
(0.03)\end{array}$ & - & - & - & - & & & \\
\hline 5. Marketing mix & $\begin{array}{c}n=4 \\
0.62 \\
(0.09)\end{array}$ & $\begin{array}{c}n=4 \\
0.63 \\
(0.05)\end{array}$ & - & $\begin{array}{c}n=11 \\
0.46 \\
(0.05)\end{array}$ & - & - & & \\
\hline \multicolumn{9}{|l|}{ Performance } \\
\hline 6. Customer & $\begin{array}{c}n=6 \\
0.49 \\
(0.08)\end{array}$ & $\begin{array}{c}n=3 \\
0.79 \\
(0.08)\end{array}$ & - & $\begin{array}{c}n=5 \\
0.54 \\
(0.05)\end{array}$ & - & $\begin{array}{c}n=6 \\
0.40 \\
(0.06)\end{array}$ & - & \\
\hline 7. Market & $\begin{array}{r}n=11 \\
0.40 \\
(0.04)\end{array}$ & $\begin{array}{c}n=5 \\
0.49 \\
(0.09)\end{array}$ & $\begin{array}{c}N=2 \\
0.33 \\
(0.06)\end{array}$ & $\begin{array}{c}n=4 \\
0.41 \\
(0.04)\end{array}$ & - & $\begin{array}{c}n=15 \\
0.44 \\
(0.05)\end{array}$ & $\begin{array}{c}n=3 \\
0.57 \\
(0.02)\end{array}$ & - \\
\hline 8. Financial & $\begin{array}{r}n=16 \\
0.29 \\
(0.03)\end{array}$ & $\begin{array}{c}n=7 \\
0.46 \\
(0.08)\end{array}$ & $\begin{array}{c}N=3 \\
0.29 \\
(0.04)\end{array}$ & $\begin{array}{c}n=5 \\
0.39 \\
(0.09)\end{array}$ & $\begin{array}{c}n=3 \\
0.39 \\
(0.06)\end{array}$ & $\begin{array}{r}n=11 \\
0.32 \\
(0.05)\end{array}$ & $\begin{array}{c}n=3 \\
0.54 \\
(0.02)\end{array}$ & $\begin{array}{r}n=8, \\
0.66 \\
(0.03)\end{array}$ \\
\hline
\end{tabular}

performance is considerably diminished. On the basis of these results, there is much reason to consider more cautiously the necessity of MO as a driver of organizational performance.

$\mathrm{H} 3$ implies that MO is more appropriately considered a capability antecedent than a performance antecedent. Bivariate relationships between $\mathrm{MO}$ and market planning and marketing implementation capabilities are large: $r_{\mathrm{MO} \text {, market intelligence }}=0.65, r_{\mathrm{MO}}$, customer relationship management $=0.42, r_{\mathrm{MO} \text {,product development management }}=0.51, r_{\mathrm{MO} \text {,product }}$ commercialization management $=0.50$, and $r_{\mathrm{MO} \text {,marketing mix management }}=0.62$. Relationships between organizational capabilities and levels of organizational performance are indicated in Table 3. Partial correlation coefficients were calculated and show that organizational capabilities play significant roles in the bivariate relationships between MO and organizational performance. For example, the bivariate relationship between MO and customer performance $(r=0.49)$ is greatly diminished by controlling for the effects of the market intelligence capability $(r=-0.04)$, product development management capability $(r=0.29)$, and the marketing mix management capability $(r=0.34)$. As Table 3 shows, it was not possible to perform this calculation controlling for the product commercialization capability as an insufficient number of studies have examined this particular issue.

\section{Concluding remarks}

One of the fundamental objectives of the market-oriented firm is to satisfy customer needs on a sustainable basis. The MO-P main-effect relationship implies that organizational 
performance derives positively from providing customers with superior value over the long run. The results of this analysis reinforce earlier findings reported in meta-analyses as to the positive and significant relationship between $\mathrm{MO}$ and performance. On its own, MO appears to possess the characteristics of a resource that is linked with superior organizational performance. Beyond this main-effect bivariate relationship, however, this paper sheds valuable light on the overall nomological network that bridges MO and performance. Results show that $\mathrm{MO}$ is actually a relatively distal correlate of organizational performance. By comparison, the organizational capabilities considered in this meta-analysis appear to be relatively proximal correlates of subjective organizational performance. This appears to be particularly true for marketing implementation capabilities. Results also indicate that multiple routes may exist to the performance benefits that are frequently ascribed to MO. The next obvious step is to conduct a meta-analytic path (or related) analysis with respect to the mediated marketorientation-performance relationship. The current meta-analysis offers some important insights, but path analysis is better able to comment on the causal nature of relationships.

\section{References}

Barney, J. (1991). Firm resources and sustained competitive advantage. Journal of Management, 15, $175-190$

Charpavang, C. (2012). The relationship among market orientation, corporate social responsibility, and marketing performance in Thailand manufacturing. International Journal of Business Strategy, 12, 36-48.

Conant, J., Mokwa, M., \& Varadarajan, R. (1990). Strategic types, distinctive marketing competencies and organizational performance: A multiple measures-based study. Strategic Management Journal, 11, 365-383.

Day, G. (1994). The capabilities of market-driven organizations. Journal of Marketing, 58, 37-52.

Deligonul, Z., \& Cavusgil, S. T. (1997). Does the comparative advantage theory of competition really replace the neoclassical theory of perfect competition? Journal of Marketing, 61, 65-73.

Deshpandé, R., Farley, J. U., \& Webster, F. E. Jr (1993). Corporate culture customer orientation, and innovativeness in Japanese firms: A quadrad analysis. Journal of Marketing, 57, $23-37$.

Ellis, P. (2006). Market orientation and performance: A meta-analysis and cross-national comparisons. Journal of Management Studies, 43, 1089-1107.

Fahy, J., Hooley, G., Greenley, G., \& Cadogan, J. (2006). What is a marketing resource? A response to Gibbert, Golfetto and Zerbini. Journal of Business Research, 59, 152-154.

Foley, A., \& Fahy, J. (2009). Seeing market orientation through a capabilities lens. European Journal of Marketing, 43, 13-20.

González-Benito, Ó., \& González-Benito, J. (2005). Cultural vs. operational market orientation and objective vs. subjective performance: Perspective of production and operations. Industrial Marketing Management, 34, 797-829.

Grinstein, A. (2008). The relationships between market orientation and alternative strategic orientations. A meta-analysis. European Journal of Marketing, 42(1/2), 115-134.

Han, J. K., Kim, N., \& Srivastava, R. K. (1998). Market orientation and organizational performance: Is innovation a missing link? Journal of Marketing, 62, 30-45.

Hong, J., Song, T., \& Yoo, S. (2013). Paths to success: How do market orientation and entrepreneurship orientation produce new product success? Journal of Product Innovation Management, 30, 44-55.

Hooley, G., Greenley, G., Cadogan, J., \& Fahy, J. (2005). The performance impact of marketing resources. Journal of Business Research, 58, 18-27.

Hsieh, Y., Chiu, H., \& Hsu, Y. (2008). Supplier market orientation and accommodation of the customer in different relationship phases. Industrial Marketing Management, 37, 380-393.

Hughes, P., Morgan, R., \& Kouropalatis, Y. (2008). Market knowledge diffusion and business performance. European Journal of Marketing, 42, 1372-1395.

Hult, G. T., \& Ketchen, D. J. (2001). Does market orientation matter? A test of the relationship between positional advantage and performance. Strategic Management Journal, 22, 899-906. 
Hult, G., Ketchen, D., \& Slater, S. (2005). Market orientation and performance: An integration of disparate approaches. Strategic Management Journal, 26, 1173-1181.

Jaakkola, M., Möller, K., Parvinen, P., Evanschitzky, H., \& Mühlbacher, H. (2010). Strategic marketing and business performance: A study in three European 'engineering countries.' Industrial Marketing Management, 39, 1300-1310.

Jiménez-Jiménez, D., \& Cegarra-Navarro, J. (2007). The performance effect of organizational learning and market orientation. Industrial Marketing Management, 36, 694-708.

Kawakami, T., MacLachlan, D., \& Stringfellow, A. (2012). New venture performance in China, Japan, and the United States: The impact of formalized market information processes. Journal of Product Innovation Management, 29, 275-287.

Ketchen, D., Hult, G., \& Slater, S. (2007). Toward greater understanding of market orientation and the resource-based view. Strategic Management Journal, 28, 961-964.

Kim, N., Im, S., \& Slater, S. (2013). Impact of knowledge type and strategic orientation on new product creativity and advantage in high-technology firms. Journal of Product Innovation Management, 30, 136-153.

Kirca, A., Jayachandran, S., \& Bearden, W. (2005). Market orientation: A meta-analytic review and assessment of its antecedents and impact on performance. Journal of Marketing, 69, 24-41.

Kohli, A. K., \& Jaworski, B. J. (1990). Market orientation: The construct, research propositions, and managerial implications. Journal of Marketing, 54(2), 1-18.

Langerak, F., Hultink, E., \& Robben, H. (2007). The mediating role of new product development in the link between market orientation and organizational performance. Journal of Strategic Marketing, 15, 281-305.

Lau, C. (2011). Team and organizational resources, strategic orientations, and firm performance in a transitional economy. Journal of Business Research, 64, 1344-1351.

Li, Y., Wei, Z., \& Liu, Y. (2010). Strategic orientations, knowledge acquisition, and firm performance: The perspective of the vendor in cross-border outsourcing. Journal of Management Studies, 48, 1457-1482.

Lin, C., Peng, C., \& Kao, D. (2008). The innovativeness effect of market orientation and learning orientation on business performance. International Journal of Manpower, 29, 752-772.

Lipsey, M., \& Wilson, D. (2001). Practical meta-analysis. Thousand Oaks, CA: Sage.

Liu, S. S., Luo, X., \& Shi, Y. (2003). Market-oriented organizations in an emerging economy: A study of missing links. Journal of Business Research, 56, 481-491.

Lonial, S., Tarim, M., Tatoglu, E., Zaim, S., \& Zaim, H. (2008). The impact of market orientation on NSD and financial performance of hospital industry. Industrial Management \& Data Systems, 108, 794-811.

Matsuno, K., Mentzer, J. T., \& Özsomer, A. (2002). The effects of entrepreneurial proclivity and market orientation on business performance. Journal of Marketing, 66, 18-32.

Menguc, B., \& Auh, S. (2006). Creating a firm-level dynamic capability through capitalizing on market orientation and innovativeness. Journal of the Academy of Marketing Science, 34, $63-73$.

Miles, M., \& Arnold, D. (1991). The relationship between marketing orientation and entrepreneurial orientation. Entrepreneurship: Theory \& Practice, 15, 49-65.

Morgan, N., Vorhies, D., \& Mason, C. (2009). Market orientation, marketing capabilities, and firm performance. Strategic Management Journal, 30, 909-920.

Morgan, R. E. (2004). Market-based organisational learning - theoretical reflections and conceptual insights. Journal of Marketing Management, 20, 67-103.

Narver, J. C., \& Slater, S. (1990). The effect of a market orientation on business profitability. Journal of Marketing, 54, 20-35.

Ngo, L., \& O'Cass, A. (2012). In search of innovation and customer-related performance superiority: The role of market orientation, marketing capability, and innovation capability interactions. Journal of Product Innovation Management, 29, 861-877.

Noble, C., Sinha, R., \& Kumar, A. (2002). Market orientation and alternative strategic orientations: A longitudinal assessment of performance implications. Journal of Marketing, 66, 25-39.

O'Cass, A., \& Ngo, L. (2011). Winning through innovation and marketing: Lessons from Australia and Vietnam. Industrial Marketing Management, 40, 1319-1329.

O'Cass, A., \& Ngo, L. (2012). Creating superior customer value for B2B firms through supplier firm capabilities. Industrial Marketing Management, 41, 125-135. 
Ogbonna, B., \& Ogwo, O. (2013). Market orientation and corporate performance of insurance firms in Nigeria. International Journal of Marketing Studies, 5, 104-116.

Ramaswami, S., Srivastava, R., \& Bhargava, M. (2009). Market-based capabilities and financial performance of firms: Insights into marketing's contribution to firm value. Journal of the Academy of Marketing Science, 37, 97-116.

Rhee, J., Park, T., \& Lee, D. (2010). Drivers of innovativeness and performance for innovative SMEs in South Korea: Mediation of learning orientation. Technovation, 30, 65-75.

Rosenthal, R. (1984). Meta-analytic procedures for social research. Beverley Hills, CA: Sage.

Sin, L., Tse, A., Heung, V., \& Yim, F. (2005). An analysis of the relationship between market orientation and business performance in the hotel industry. Hospitality Management, 24, $555-577$.

Singh, S. (2009). How market orientation and outsourcing create capability and impact business performance. Thunderbird International Business Review, 51, 457-471.

Slater, S. F., \& Narver, J. C. (1995). Market orientation and the learning organization. Journal of Marketing, 59, 63-74.

Srivastava, R., Shervani, T., \& Fahey, L. (1999). Marketing, business processes, and shareholder value: An organizational embedded view of marketing activities and the discipline of marketing. Journal of Marketing, 63, 168-179.

Tay, J., \& Tay, L. (2007). Market orientation and the property development business in Singapore. International Journal of Strategic Property Management, 11, 1-16.

Verhoef, P., \& Leeflang, P. (2009). Understanding the marketing department's influence within the firm. Journal of Marketing, 73, 14-37.

Vorhies, D., \& Morgan, N. (2005). Benchmarking marketing capabilities for sustainable competitive advantage. Journal of Marketing, 69, 80-94.

Weerawardenaa, J., \& O'Cass, A. (2004). Exploring the characteristics of the market-driven firms and antecedents to sustained competitive advantage. Industrial Marketing Management, 33, $419-428$

Wu, S., Melnyk, S., \& Flynn, B. (2010). Operational capabilities: The secret ingredient. Decision Sciences, 41, 721-754.

Yang, Z., Wang, X., \& Su, C. (2006). A review of research methodologies in international business. International Business Review, 15, 601-617.

Yannopoulos, P., Auh, S., \& Menguc, B. (2012). Achieving fit between learning and market orientation: Implications for new product performance. Journal of Product Innovation Management, 29, 531-545.

Zhou, K., Brown, J., \& Dev, C. (2009). Market orientation, competitive advantage, and performance: A demand-based perspective. Journal of Business Research, 62, 1063-1070.

Zhou, K., Li, J., Zhou, N., \& Su, C. (2008). Market orientation, job satisfaction, product quality, and firm performance: Evidence from China. Strategic Management Journal, 29, 985-1000. 